\title{
Importance of Voting at the Municipal Level: The Seniors' Voices
}

\author{
Salomé Vallette* \\ Centre de Recherche sur l'urbanisation et la Culture (INRS), Montréal City, QC, Canada
}

While municipal elections in Quebec are characterized by low voter turnout, it appears that people over 65 years old are the ones who vote in higher numbers. In fact, this is the case for both federal and provincial elections. However, the lack of individual data on municipal elections does not yet allow us to say that seniors vote more than younger people. This finding invites political scientists to look at the electoral behaviour of individual voters and the importance attached to the act of voting at this level of government. In addition, the majority of studies on elections focus on the behaviours of voters living in large cities such as Montreal or Quebec City. In Quebec, the few studies that have looked at medium size municipality voting behaviour have mainly studied the cities of Quebec City, but not Montreal. Based on 19 interviews conducted with people aged between 65 and 84 and living in one medium size cities, Saint-Jean-sur-Richelieu, our research illustrates the

OPEN ACCESS

Edited by: Jérôme Couture, Laval University, Canada

Reviewed by:

Andreas C. Goldberg, University of Amsterdam, Netherlands Francisco Cantu, University of Houston, United States Andrea Perrella, Wilfrid Laurier University, Canada

*Correspondence: Salomé Vallette salome.vallette@inrs.ca

Specialty section: This article was submitted to Elections and Representation, a section of the journal Frontiers in Political Science

Received: 06 July 2021 Accepted: 10 September 2021 Published: 11 October 2021

Citation:

Vallette S (2021) Importance of Voting at the Municipal Level: The Seniors' Voices.

Front. Polit. Sci. 3:737315. doi: 10.3389/fpos.2021.737315 importance of the exercise of a duty, the access to political information, the proximity of electoral behaviour and the influential role of seniors. According to participants, it is easier to talk to municipal candidates and get to know the person who will become their official representative, compared to the provincial and federal levels where it is more difficult to talk to candidates. Also, their knowledge of the municipal political system is better than when they were younger. While voting is similarly important at each level of government, participants felt that voting at the municipal level is directly relevant to them because of the municipal services but also by the influence they can have on their councillor.

Keywords: municipal level, elections, electoral behaviour, seniors 65 and over, medium size municipality, Quebec

\section{INTRODUCTION}

In Quebec, the demographic weight of seniors is growing rapidly and will continue to increase in the coming years with the arrival of baby boomers in the $65+$ age cohort (ISQ,Institut de la statistiq du Québec, 2015). This increase is not without consequences for the participation of this age group in society's future. Indeed, we know that the older a person gets, the more likely he or she will be to become involved in his or her social and political environment (Jennings, 1979; Elder and de Richard, 1998; Gherghel and et Saint-Jacques, 2013). Indeed, electoral data from recent federal and provincial elections in Quebec establish that the turnout rate of those 65 and older is higher than other age categories (Élections Canada, 2016). The demographic increase of seniors and their greater electoral participation than that of other categories of voters represent a significant electoral weight in contemporary society.

Over the past decade, several Canadian researchers have examined municipal elections, including McGregor (2018) with the Canadian Municipal Election Study. This study addresses the themes of Internet voting, the importance of school boards in managing the administrative functions of the education sector in eight Canadian cities (Vancouver, Calgary, Winnipeg, London, Mississauga, Toronto, Montreal and Quebec City) (McGregor, 2018). Also, the Canadian Municipal Barometer 
study, which began in 2019, focuses on municipal democracy and offers, for the first time, results on all Canadian municipalities with a population of more than 9,000 in relation to municipal politics, political and electoral participation, and democratic representation in municipalities (CMB-BMC, 2020). In Quebec, several studies have also been conducted to better understand voters at the municipal level. For example, less than one in two voters goes to the polls during municipal elections (Lavoie, 2017). Since the municipal level is often considered a homeowner democracy, Mevellec (2011) shows that homeowners vote in greater numbers than renters at the municipal level. They vote more than renterss because they make greater use of municipal services (Couture et al., 2014) and have better access to political information, so they are better informed and more engaged in local politics. As Couture et al. (2014) explain, compared to renters, homeowners have more information about how their municipality is being managed through their tax bill. Moreover, depending on the decisions made by elected officials, the value of a property may be affected (Couture et al., 2014). As a result, homeowners are more likely to vote in municipal elections based on this information. Information is a variable that also has an effect on the age variable at the municipal level. In 2020, (Breux and Vallette) showed that some young voters see the municipal level as not very understable and accessible. This relationship between information and age supports the idea that younger voters consider themselves to be insufficiently informed about the municipal level (Milner, 2008). Also, Nakhaie, (2006) points out that the influence of age on voting behaviour is the same at the municipal level as at the provincial level. The results of Couture et al. (2014) show that, in Quebec, voters aged 70 and over vote more than voters aged 18 to 34 and those aged 35 to 69 . The statement that the older a voter gets, the more likely he or she is to vote seems to apply at the municipal level as well.

While current studies provide a better understanding of the evolution of voter turnout and a profile of the voter, they do not highlight the motivations of voters to go to the polls. By focusing on the voters themselves and asking them directly why they vote and why it is important for them to go to the polls, my study will provide a more complete electoral profile, especially for the municipal voter. Despite the presence of analyses of voting behaviour at this level of government, many grey areas remain, particularly regarding the importance of municipal voting associated with older voters. Being a homeowner and having a better knowledge of the municipal level of government does not allow us to understand the importance attached to their vote. So, why do older people care about municipal elections in Quebec?

To answer this question, I will first review the characteristics of the municipal voter and the specificity of the municipal level, in order to outline the studies and definitions associated with voting at the Quebec municipal level among senior voters. Then, based on 19 interviews with voters and non-voters aged 74 in SaintJean-sur-Richelieu, I will present motivations, meanings and usefulness of voting at the municipal level among this electorate. This research shows that voting at the municipal level is, for some participants, more important than voting at other levels of government. It represents an important duty to exercise and expresses the importance of voters' proximity to elected officials and to the city's service offerings. Viewed through the lens of critical gerontology and grey power theories, the results offer new insights into the importance of the senior vote for the municipal level; among other things, the role that voters assign to themselves, as seniors, to improve society through the exercise of their vote.

\section{WHO IS THE MUNICIPAL VOTER}

\section{Voting, a Gesture Linked to the Life Cycle}

In a democratic system based on the principle of one vote per person, it follows that there will be a greater number of older people with the power to vote. Blais (2002) shows, for federal elections, that "between the ages of 20 and 30, turnout increases by 7 to 8 points, between 30 and 40 , by 4 to 6 points, between 40 and 50 by 2 to 3 points, remains stable between 50 and 70 , and begins to decline thereafter." (p. 48) Indeed, for Quintelier (2007) young people lack resources regarding the electoral process, whereas older people have accumulated them throughout their lives. Young voters will gain experience as they get older and, in addition to their electoral learning, they will establish their place of residence and will succeed in developing a sense of belonging to their community (Quintelier, 2007). Thus, as Elder et al. (2003) note, life-cycle effects have always existed and are a normal part of a voter's journey. Furthermore, with each individual's unique experience, such as education, employment, personal relationships, parenthood, and retirement, could influence how they vote across the ages (Davidson, 2014). Thus, younger and older voters are simply at different stages of their lives. In contrast, longitudinal analyses by demographers across the life cycle tend to show that the aging of the electorate is no longer considered as a whole, but rather as a process of renewal of cohorts that reshape the electorate in turn (Martel, 2002). Moreover, life-course theories help explain, in part, why older people vote more than younger people. These theories explain that all of an individual's trajectories (family, educational, professional, residential) refer to a change in state, status, or role in individuals (Elder et al., 2003; Gherghel and et SaintJacques, 2013). Thus, the many years of life experience and also knowledge gained about the municipal political system are likely to guide voters toward voting. The electoral participation of seniors has also been studied, for the past thirty years, by the concept of grey power. This concept assumes that older citizens become aware of their demographic weight and assert their interests by exercising their right to masse voting (Vincent, 1999; Goerres, 2008; ViriotDurandal et al., 2012). It also refers to the study of the effects of aging on a generation, whether working or retired, whose life course has been marked by opportunities for social and economic ascension (Davidson, 2014). Also, as Viriot Durandal (2013) mentions, the reference to the number of the potential group, the retired, is symbolic. It does not imply any concrete step of membership or support on their part.

For others, gray power is seen as a political claim (Ulysse and et Lesemann, 1997). They explain that "this perception of old age is rooted in the ability of older people themselves to organize and mobilize to defend their rights and interests" (Ulysse and et 
Lesemann, 1997, p.13). Over the past few decades, Canada, the United States and Great Britain have seen an increase in pressure groups organized by older citizens whose goal is mainly to defend their gains while creating new opportunities (Walker, 1983; Pratt, 1993; Binstock and et Day, 1996). According to Carette and et Lamont (1988), grey power could also be identified with managerial and organizational power. The authors state that this power allows seniors to demand control and management of their daily lives: "they would demand better adapted and better financed services, or denounce the paternalism of all kinds of workers, or the patriarchal regime imposed on them by the men who preside over their clubs or groups" (Carette and et Lamont, 1988, p.137). This is because the generation of seniors is more educated and therefore more critical of their conditions than the previous generation of seniors (Ulysse and et Lesemann, 1997). Context is also related to the particular situation of the baby boomer generation, which is the "generation of change, [...] it carries with it the vision of change. Therefore, a strong impact on participation rates is expected from them" (Viriot Durandal et al., 2015, p. 211).

Grey power is a matter of demographic weight. Martel (2002) compares the proportion of 18 to 34 year olds with that of 65 and over and concludes that Quebec will witness a "transfer of power [where] for the first time in history, the elderly will have more votes than the young. Seniors, by their numbers, but also by their propensity to vote, are therefore gaining political power that younger age groups do not have. It is taken into account that the elderly are a political force both in their electoral power and in the creation of lobbies wanting to defend their collective interests (Viriot-Durandal, 2012). Taking into account the changing age profile of the electorate, elected officials will want to satisfy the demands of older voters, concerned about their retirement and adequate and sufficient health care services (Davidson, 2014). For Davidson (2014), Downs' notion of rational choice ${ }^{1}$ offers a theoretical explanation for why age transformation could lead to the exercise of gray power, particularly if older voters took a common view of electoral issues. Arguably, voting is more rational for a group that can expect to benefit from a particular outcome rather than as an isolated individual. In contrast, Davidson (2014) questions whether older people, as a group, have a shared perception of policies that would satisfy their social and economic demands. However, while gray power is often predicted, it is rarely observed (Goerres, 2008; Davidson, 2014). Despite this, some political parties are implementing strategies to attract the seniors' vote. This is the case of the 50Plus parliamentary party in the Netherlands, which focuses on the interests of older people through policy issues related to pensions, retirement and health care (Laurence, 2021). Only fou seats (out of 150) were won in parliament in the 2017 general election (Laurence, 2021).

These perspectives of gathering older people to claim their rights and needs, create an image of the ideal elder who contributes to society and does not become an economic burden (Martinson and et Halpern, 2011; Joy, 2018). Critical

\footnotetext{
${ }^{1}$ As Downs explains, voting is a matter of calculation between the cost and the benefits of that vote: "If the returns outweigh the costs, he votes; if not, he abstains" (Downs, 1957, p. 260).
}

gerontology scholars thus tend to limit the normalization and instrumentalization of political participation that contribute to forming an injunction to make one of the elder an active being in all areas, including electoral participation.

Some research in the United States also demonstrates that high voter turnout among older adults is not new. In the early 1990s, Quadagno (1991) found that people aged 65 and older voted almost three times as much as 18-24 year olds over the previous four decades. Subsequently, in studying the last forty years, Campbell et al. (2011) also noted that the turnout rate of those 65 and older has, on average, steadily increased in contrast to other age categories. However, several studies also show that the gap in voter turnout between young and older voters is not due to life-cycle effects, but rather to generational differences. Indeed, Blais et al. (2004) and Franklin (2004) explain that younger generations of voters are less likely to vote than older generations of voters. Yet according to Dassonneville (2017), "regardless of evolutions over time in turnout and differences from one election to another or generational differences, the basic relationship between age and turnout is the expected curvilinear one." (p. 9) She also adds that middle-aged voters are the ones who would be most likely to vote on election day. While these studies are not unanimous on the exact age at which a voter is more likely to vote, it is possible, based on Blais et al. and Franklin, to focus on the baby boomer generation. According to data from the federal and provincial elections in Quebec, people aged 65 and over, characterized by the baby boomer generation, are the most likely to vote. Thus, $57.1 \%$ of $18-34$ year olds voted in the 2015 federal election compared to $78.8 \%$ for $65-74$ year olds and $67.4 \%$ for 75 year olds and older (Élections Canada 2016), and $81.89 \%$ of 65-74 year olds voted in the Quebec provincial election compared to $55.69 \%$ for $18-24$ year olds (Chaire de recherche sur la démocratie et les institutions parlementaires 2014, p. 10).

\section{Municipal Elections, Less Important Elections}

The literature contains many studies on the factors that explain electoral participation, but little information on the explanation of electoral participation among seniors. These studies, usually address the provincial or national level: the municipal level is still little studied despite a renewed interest in this level of government in recent years (Breux and et Couture, 2018). As a result, studies of models to explain voting highlight the weight of socio-demographic variables (gender, income, etc.). The best known focus on the status of the individual, namely gender, income and employment (Geys, 2006). In North America, these various studies on the factors of electoral participation deal mainly with the federal or provincial level. Few studies address the municipal level. This can be explained by the low level of centralization of electoral data, but also by the fact that some authors consider the municipal level to be distinct from other levels.

It should be noted that few studies focus on the municipal level. In fact, studies of municipal elections are the poor cousins of political science and this situation is not unique to Canada (Bherer and et Breux, 2011). It is also the case in the United States and France (Cutler and et Scott Matthews, 2005). This can be explained by the fact that studies in 
electoral behaviour have progressively decreased while economic theories of rational choice have taken a significant place in the analysis of electoral behaviour (Mayer, 2007). Also, according to Eidelman and et Taylor (2010), local and municipal politics is, to a large extent, seen as subordinate and derivative of provincial and federal dynamics, primarily through intergovernmental relations. This was the case for Quebec.

Indeed, in 2017, Quebec passed the Act-122 mainly to recognize that municipalities are local governments and to increase their autonomy and powers, allowing municipalities to perform essential functions and provide services to their population (INSPQ, 2019). This differentiates the Quebec municipal political system from other municipal political systems in other representative democracies. Until 2017, Quebec municipalities had powers and responsibilities, but they were often seen as provincially governed. In France, Germany and Belgium, municipalities have enjoyed a similar legal status for a longer period of time (Wollmann, 2016). Also, in Quebec, political parties at the federal and provincial levels are not present at the municipal level. When political parties are present at the municipal level, they are specific to a single municipality and do not clearly position themselves on a left-right axis (Mevellec et al., 2020), compared to other democracies, such as France, where political parties are present at all levels of government.

Quebec is the only Canadian province to have a law that regulates municipal political parties. However, Quebec's municipal government is still the one with the lowest presence of political parties; for 1,100 municipalities, there are 172 political parties (Élections Québec, 2021). But political parties are necessary for the transmission of information and promote the presence of an opposition, thus allowing diversity in the electoral offer (Breux, 2013). In fact, the superior levels of government run many candidates in their elections, whereas competition is weak in Quebec municipal elections, as incumbents are re-elected or because candidates win their election by acclamation (Breux and et Couture, 2018). Gutzke (2021) recent study analyzing 2017 election data shows that $61.04 \%$ of elected mayors were incumbents and $51.15 \%$ of elected mayors won their election by acclamation. These high rates of acclaimed elections mean that elected officials did not have a conversation with political opponents about their municipality services or the future of city management; important elements of municipal democracy and representation of voters' needs. Also, according to Trounstine (2009), the specificity of the municipal level makes it difficult for factors that explain voting behaviour, at a superior level of government, to explain municipal voter turnout. Moreover, Breux, Couture and Goodman (2017) have shown that Down's rational voter model explains only $45 \%$ of municipal voter turnout in Quebec elections.

These particularities of the Quebec municipal level lead me to understand whether the importance, as well as the interest and motivation, of voting at the municipal level can be different from other elections at superior levels of government.

However, although the profile of the municipal voter is incomplete due to a lack of individual data, we do know several elements that make the municipal level unique: low voter turnout, homeowners voting and proximity to elected officials.
As mentioned earlier, voter turnout at the municipal level is lower than at other levels of government. It varies between 50 and 55\% depending on the election (Collin and et Bherer, 2009). However, we know that the size of municipalities changes the rate of participation. This suggests that voter turnout at the municipal level is not so low, but rather that the overall average for all municipalities suggests that turnout is lower. Indeed, Collin and et Bherer (2009) state that voter turnout is related to the demographic size of municipalities, the more inhabitants the municipality has, the lower the voter turnout will be, and this is true in Quebec, in Canada and elsewhere in the developed world. For smaller municipalities, the rate of elections by acclamation is higher, without being absent in larger municipalities (Collin and et Bherer, 2009).

This can be explained in two ways. On the one hand, some studies (Oliver, 2000; Blais, 2006; Cancela and Geys, 2016) claim that social networks are less structured in large cities, that citizens have a lower proximity, while the opposite occurs in small cities: residents get to know each other, social networks are closer and stronger, leading to a greater mobilization and political participation. On the other hand, it seems that the greater the physical proximity of the residents in a large municipality, the greater the social pressure of a group, exerted by the citizens, will be; this also favours the political participation of the citizens (Blais and Dobrzynska, 1998; Endersby and Krieckhaus, 2008). On the other hand, the social network and proximity of the citizens in a medium-sized municipality has not yet been explored in Quebec. These municipalities are often those located on the periphery of large municipalities. Also, the municipal level is often seen as a homeowner democracy, which can be seen as a barrier to renter voters (Mevellec, 2011). In Canada, based on aggregate statistics, McGregor and et Spicer (2016) demonstrate that homeownership is an important factor in voter choice at the municipal level. Homeowners vote in greater numbers than renters and their overrepresentation may leave renters with less influence at the municipal level. Homeowners vote more than renters because they have better access to political information and make greater use of municipal services (Couture, Breux, and Bherer, 2014). The phenomenon is similar in the United States. The American municipal voter is older, wealthier, more educated than average, and a long-time resident of the municipality. According to Oliver et al. (2012) long-term residents are more likely to vote because they are better informed and more engaged in local politics than the average voter in national elections. Indeed, it appears that homeownership influences attitudes toward public policy, as homeowners are less likely to support the construction of new public housing and are particularly opposed to municipal mergers than renters (McGregor and et Spicer, 2016).

All of these features of the municipal level help to explain why models of voter turnout are difficult to apply to this level of government. Moreover, these different characteristics of the municipal voter do not specifically apply to seniors: we know that seniors vote more than other voters, but we do not know yet their voting behaviour at the municipal level.

In short, the lack of knowledge about the electoral behaviour at the municipal level can be explained by two factors. First, there is a lack of interest in electoral studies at this level of government. Second, studies of explanatory models of voter turnout are more 
concerned with economic theories than with sociological and psychological models.

Thus, by analyzing seniors' voting participation at the municipal level, it will be possible to understand the importance of this act and the meaning it has for them in their society. Despite the lack of knowledge about the representation of voting at the municipal level among seniors, grey power theory allows us to understand, without certainty since it has never been empirically studied, the importance of voting for seniors at national levels.

\section{METHODOLOGY APPROACH}

A qualitative approach with individual data is necessary to understand why seniors give importance to municipal voting. Therefore, interviews appear to be an appropriation information gathering tool for my research, since they allow the researcher to develop an understanding of a phenomenon (Savoie-Zajc, 2009), in my case why it is important to vote at the municipal level for seniors. Unlike a survey, an interview is a device that makes it possible to capture, through an exchange between a researcher and a participant, the point of view of individuals, their understanding of a particular experience, their vision of the world, in order to make them explicit to understand them in depth or to learn more about a given object. Since the floor is given to the individual, the interviews proves to be a privileged instrument for uncovering his or her representation of the word (Baribeau and et Royer, 2013). In addition, a socio-demographic questionnaire was completed by the participants of my research.

This questionnaire was presented at the beginning of each interviews following the ethical explanations. The questionnaire asked participants about their age, gender, education level, current occupation, sector of employment, marital status, health status, financial situation, whether they owned or rented, who they lived with, and finally how long they had lived in the city. Among other things, these questions allow us to test for potential links between socio-demographic characteristics and voter turnout at the municipal level, and to see if these links are the same, as we know, at higher levels of government.

I conducted 19 interviews with people between 65 and 85 years old, living in Saint-Jean-sur-Richelieu ${ }^{2}$. The recruitment was done with the help of associations and community and social organizations. Invitation emails were sent to all these associations and organizations in the city of Saint-Jean-sur-Richelieu. The

\footnotetext{
${ }^{2}$ Test interviews were conducted with students at my university, younger than the older group age that I am studying. The students were at the master's level as well as at the doctoral level and had the knowledge related to a university research. I also conducted two test interviews with my parents, who did not live in Saint-Jean-surRichelieu. The objective of these tests was to test the argumentative thread of my guide, to have an approximate idea of the duration as well as to have feedback from the students on the methodological process of the interviews and from my parents on the comprehension and ease of the language used. These tests proved to be successful as the guide and the argumentative thread did not receive any criticism. These interviews are not included in the analysis.
}

interviews were conducted either at the participant's home, in a public place, by telephone or by videoconference software. The purpose of the interviews was to obtain knowledge about the importance of voting at the municipal level, its use and its distinction from voting at other levels of government, while focusing on a biographical approach to the electoral participation of senior participants. In addition, they allowed for more specific and personal elements specific to each participant. As for the argumentative thread of the interviews, the first questions aimed to find out the participants' sense of belonging to the municipality (Do you like Saint-Jean-surRichelieu? For what reasons?), then the discussion turned to the use of the three municipal services, namely transportation, the library and the municipal parks (What type of transportation do you use in the city? Do you use the city's public transit system? Why?/Do you use the city library?/Do you use the city parks?) After the more specific questions about the city, questions about voting at the municipal level were asked. These questions asked about participation in municipal elections (Do you vote at the municipal level?), the significance of voting at the municipal level compared to other elections (Is it important to you to vote at the municipal level? More than other levels of government? Why?) and how their vote has changed over time (Is your vote at the municipal level different today, as a senior, than it was before? Is it more or less important today?) Finally, the discussion concluded with questions about the usefulness and contribution of their vote (How useful do you find voting at the municipal level?/Finally, in what ways do you consider your vote at the municipal level to be a contribution to society?).

The final sample consists of 19 participants. This sample was conducted between October 21, 2019 and December 07, 2020. The average ages of our individual interviews is 74 years old. The sample consists of 9 males and 10 females. Only one participant expressed not voting at the municipal level, all other participants mention performing this electoral act. This participation rate is well above the average participation rate for the general population provincially (Breux and et Couture, 2018). For the purposes of this research, the municipal level is represented by medium size municipalities near Montreal, i.e., between 20,000 and 99,999 inhabitants (Mevellec, 2011). This choice is based on the desire to provide a better understanding of these municipalities, which are neglected in academic work to the detriment of large Canadian metropolitan cities. Also, as mentioned above, the proximity of residents and the social network in medium-sized municipalities are not yet explored. There are fifty Quebec municipalities that can be categorized as medium-sized municipalities, but the disparity in the size of the municipalities offered by Mevellec's categorization (2011) leads us to establish more precise criteria. Three criteria have been established: 1- the stability of the electoral participation rate, at the municipal level, 2- the rate of aging similar to that of Quebec, in order to avoid having a municipality that is too old or too young, and 3- the distance from a metropolis.

Thus, Saint-Jean-sur-Richelieu, with a population of 98,036 (2016) meets all these criteria. As shown in Table 1, the participation in the last municipal elections is relatively stable, besides an increase in 2013. Regarding the aging rate, Saint-Jean- 
TABLE 1 | Changes in voter turnout in municipal elections in saint-jean-surrichelieu.

\begin{tabular}{llll}
\hline $\mathbf{2 0 0 5}$ & $\mathbf{2 0 0 9}$ & $\mathbf{2 0 1 3}$ & $\mathbf{2 0 1 7}$ \\
\hline $39,0 \%$ & $43,0 \%$ & $49,9 \%$ & $41,9 \%$
\end{tabular}

sur-Richelieu has a rate of $18.2 \%$, which is similar to the rate of the province of Quebec which is 18.3\% (Statistics Canada 2016). Finally, the city is located about $40 \mathrm{~km}$ from the city of Montreal.

It should also be noted that the doctoral research, of which this article presents only part of the results, focused on three mediumsized municipalities surrounding the large city of Montreal. SaintJean-sur-Richelieu is one of these municipalities.

This sample obviously has limitations, like the fact that participants are all involved in their communities, which leads them to participate politically more than others. This choice to recruit with volunteers is a result of the difficulty of reaching individuals who do not participate. It was also difficult to reach participants in health care facilities or in residential housing for the elderly.

The analysis of our data was carried out in two stages. First, a so-called "floating reading" (Baribeau, 2009) of the testimonies transcribed in their entirety, was carried out. This floating reading allowed common themes to emerge. Secondly, NVivo software was used to code the various statements by theme, the terms that emerged during the first reading, and by collection tools. Finally, a more in-depth analysis was done with the themes and according to the questions asked during the interviews to answer our research question.

\section{RESULTS}

\section{Love Your City, but Not Its Services}

The 19 participants have been living in the municipality of SaintJean-sur-Richelieu for an average of 42 years. They also express pride in living there: "Now I can say that Saint-Jean-sur-Richelieu has adopted me"3 (Participant 5). For all the participants, the city is very much appreciated: "I am a true Montrealer. But I came to Saint-Jean in the 1950s, I left the military college, I came back to work at the college. Since then, I've been here for 47 years!" (Participant 6). This rootedness and appreciation of the city could be explained by the use of city services. Indeed, according to Rochman and Tremblay (2010), the quality of life of citizens may depend on the services available to them.

First of all, public transportation services are little used by seniors for their trips within their municipality. The senior participants consider that they are in full possession of their autonomy, that they are not old enough to use it, and that they prefer to use their own vehicle: "I have never taken it. I know it's there, I know it exists, I see people coming to take it." (Participant 12). Nevertheless, as far as intercity services are concerned,

${ }^{3}$ The focus groups and interviews were conducted in French. We have translated the participants' statements. seniors use them to travel outside the city of Saint-Jean-surRichelieu: "The intercity service is excellent between Saint-Jeansur-Richelieu and Montreal. Then you get to the heart of the city. We have access to everything." (Participant 6).

Then, several services, such as computer courses, workshops and cultural activities are offered in three libraries of the municipality. It seems that all of these services are known by the participants: "free meetings on Sundays, authors' conferences, music [and] musicians" (Participant 4). But book borrowing remains the main activity carried out at the library by women. In fact, it is mainly women who use libraries. Men know and appreciate the three institutions, but reading is not part of their leisure time. One man explained that he saves time by listening to news reports rather than reading books: "In 1 hour, a good news report, it can be about literature, for me it's like reading a book that will take you 5 hours. It saves time!" (Participant 11)

Finally, since there are a significant number of parks in the municipality of Saint-Jean-sur-Richelieu, it seemed interesting to verify if the participants frequent them. According to the sector of the city where they live, the participants frequent or not the parks. Indeed, those who live in the rural sector of the city say that they do not use the parks, because the layout of the parks does not meet the needs of seniors: "Next year they will install [...] water games. For the kids again! But I don't see grandma going under a water feature. [...] What's there for the old people? (Participant 7) However, those living in the central neighborhoods of Saint-Jeansur-Richelieu say the opposite: "They are well equipped [and] they are safe." (Participant 17) When they go to parks, participants from the central neighbourhoods do so to enjoy nature or to play sports, such as skating on "an ice rink through the trees in the park" (Participant 18).

Thus, municipal services are used to a greater or lesser extent by senior participants in Saint-Jean-sur-Richelieu. The participants do not use the public transport service which is at their disposal to move in the city. In fact, they prefer to use their car which seems to reflect their autonomy. Also, there is a distinction in libraries use between men and women. Men do not use the city's libraries, but are aware of the services offered, while women often use these facilities, both to rent books and to access training workshops or listen to lectures. Finally, the use of parks was not similar among participants. Those in rural areas do not go to parks, as they consider them to be primarily for younger people, while those in the inner city use municipal parks as a place to rest or for sports activities.

\section{One Level of Government More Important Than the Others}

Among the 19 senior participants living in Saint-Jean-surRichelieu, only one participant mentioned that he does not vote at the municipal level. The 18 other participants vote at the municipal level and consider it "a duty" (Participant 7, Participant 9). A duty that, for some participants, gives citizens the opportunity to change something (Participant 9). Also, the meaning given to their vote is linked, as a right and an opportunity to express their point of view: "If you don't vote, what do you have the right to? Do you have the right to reply? To ask?" (Participant 9). Senior participants, men as women, also 
stated that voting at the municipal level is important because it allows them to support "a councillor who represents us" (Participant 7).

Voting at the municipal level is also useful for some of the participants. Voting at the municipal level can make a difference in their municipality, as they can "control" (Participant11), the elected officials on their municipal council. Indeed, as participant 17 expresses it: "You have to go and say whether you are satisfied or not, it is by voting that you can tell them. [...] If we are satisfied with our councillor in our ward, we will vote for him, if we are dissatisfied, we vote for the other one." For others participants, the usefulness of voting at the municipal level, translates into participating in municipal democracy: "For sure, my vote won't change much [...] But the way to show my support or my refusal, is to go and vote." (Participant 7) However, for other participants, voting at the municipal level is not useful: "If half of the population doesn't vote, the person who is going to be a councilor might come in first, but with what part of the population?" (Participant 5) In order for one's vote to be useful, then, it seems that more participation in these elections would be needed.

Participation in municipal elections is not the only one that participants engage in. For this reason, I asked participants if they value elections at the municipal level differently than at other levels of government. For four participants, "it is equally important" (Participant 6) for each of the elections, whether they are for the federal, provincial or municipal level. However, two participants suggest that elections are "technically different" (Participant 6). The federal level deals with the country, the provincial level deals with Quebec's activities, while the municipal level deals with citizens (Participant 7). In the same vein, only one participant explained that governments have a different importance in terms of their jurisdiction and hierarchy. She makes a comparison to the world of work: "there is a hierarchy, like the employee, the manager, and then the big boss." (Participant 17) However, seven other participants consider the municipal level to be more important than the other two, as shown in Figure 1: "I think the municipal level is the most important" (Participant 9). Among other things, this means being able the directly elect their mayor at the municipal level, whereas they cannot directly elect their prime minister in provincial and federal elections. In the same idea, participant 7 explains that "the municipal level addresses the individual, the provincial level addresses groups of individuals, while the federal level addresses almost no one." Thus, for four of these six participants, the order of importance of the levels of government is as follows: municipal, provincial and federal, where the municipal level is the most important and the federal level the least important. There are two reasons why this level is more important. The first, expressed by participants, is the provision of services that directly affect citizens (Participant 10). Municipal election issues deal with services that are used by the citizens of the city. The second reason mentioned was proximity. Proximity to services, but especially proximity to the city councillor. Participants stated that they know their Councillor well and that they are easily accessible: "For me, it's the municipal. It affects you directly [and] when you have a claim to make, or a request, you know that your [councillor] is nearby" (Participant 2). Finally, for one participant, the importance of voting is the same from one level of government to another. However, for him, it is the value of the vote that is different, since the vote at the municipal level is the one "that is closest to us" (Participant 12). This was also mentioned by other participants when asked about the value of voting at the municipal level.

\section{A Change in Motivation With Advancing Age}

Finally, I touched on the question of the evolution of the vote with the participants. For some of them (9/19), there was no evolution in their vote and their motivations are always the same: "There is no change for me. In my life, since I've been voting, it's been the same." (Participant 3) This vote has "always been important" (Participant 19) for these participants. For the others (10/19), there has been an evolution in their vote at the municipal level. This evolution translates, among other things, into a change in status, from renters to owner: "I find it more important when you are an owner. When you own a house, you feel like you need to go to vote in municipal elections." (Participant 9). There is also an interest in the municipal level that has developed, "We're more interested in it because we have more time." (Participant 11) This interest in the municipal level, and therefore in municipal elections, takes shape through the desire to see society evolve for future generations: "It's a bit of a paradox, in the sense that, these are changes that others will benefit from. That is often said. I'm going to vote, but not for me, for those who follow me" (Participant 7).

In order to find out what has influenced the evolution of their voting, some participants say that their vote has always been related to the candidate, whether it was for the program or the ideas. It is the personality of the candidates that has always interested him/her (Participant). Another element is related to the municipal services and what the candidates can offer: "I look at the individuals in place and I analyze according to what an individual is willing and able to bring. How they bring it. That's where my decision will be made, to vote" (Participant 12). Three participants, however, expressed that there is an evolution in their vote at the municipal level, but a negative evolution. The first one explains that he voted, that he no longer voted and that he doesn't know if he should continue to vote, since the municipality works with bribes (Participant 2). For another participant, it is not corruption, but rather laziness that explains why she has less motivation to vote at the municipal level: "I have less motivation, I find that older people are a bit lazy, from a political point of view. Because the older you are, the more you just think about yourself." (Participant 9) The third participant instead states that his vote no longer has the same impact since the municipal merger of 2001: "It has changed a lot, we others had a merger with the city. So before, it was for the parish. It doesn't have the same meaning today as it did 30 years ago, 40 years before the merger." (Participant 8). On the other hand, for the majority of the participants, there is a positive evolution to their vote. One participant explained that the first time she voted at the municipal level was when she was 21 years old, out of a desire to be a woman: "The first time, I voted because I wanted, as a woman, to give my voice. It was new, and I wanted to vote against 


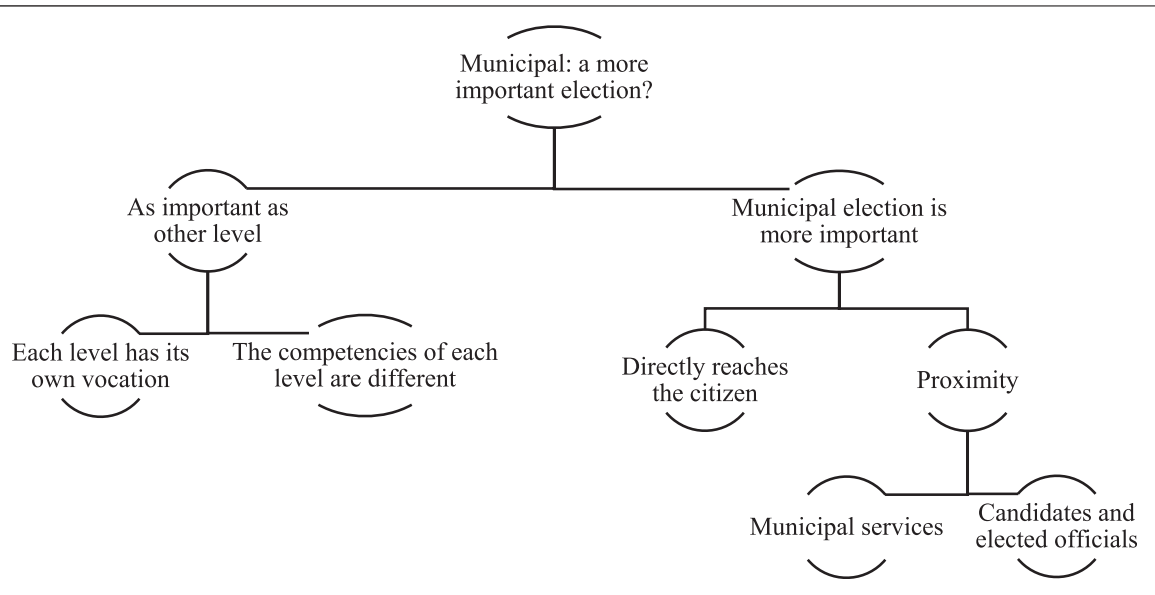

FIGURE 1 | Representation of participation in municipal elections for seniors.

my husband at the time [laughs]. I wasn't convinced he was voting for the right person, so that was my first affirmation of being a woman who could vote [laughs]" (Participant 10). Today, she votes out of conviction, "I don't vote as a woman who speaks up anymore, I vote out of conviction now, for a cause. The fact that I am a woman is no longer in the picture [laughs], but it was important back then" (Participant 10). One participant states that she "doesn't value her vote any more" (Participant 1), but that the motivation has changed over time, based on specific issues: "when my kids were little, it was to have parks, [...] after the merger, I always supported them [the projects] regarding the need for municipal identity, it's important for a city" (Participant 1). Instead, one participant explains that it is his involvement in the city that has caused a shift in his voting intention: "I have a better ear, but from my involvement in organizations, from my continued and sustained support." (Participant 7) Another participant sees the evolution of her motivation to vote at the municipal level more through the acquisition of information and knowledge about the municipal political world: "If I go back to 1982, when I am a person who knows little about Saint-Jean, who does not know the city council at all, I had to rely a little on what my neighbours and then friends told me to equip me. Now I know all the council members very well, I know the mayor very well, so I vote more knowledgeably." (Participant 5) A fifth participant states that he grew up in a political and politically involved family, but that it was his military training that forged these new motivations for electoral participation: "Let's say that I grew up, from my parents, my father, my paternal grandparents, in this political world, but I didn't necessarily realize that it was happening like that. [...] The fact of my military training, it makes us much more aware of our civic duties." (Participant 6) Today, it is his experience that guides him in his vote: "I believe in it even more, in the sense that the older I get, the more I know the system. I have experienced the system. I think that political maturity is a bit like intellectual and cultural maturity. I think that it is acquired, it develops as we get older (Participant 6). Finally, only one participant expressed the fact that she started voting, in municipal elections, a little over 30 years ago, "I was in
Saint-Jean, but I wasn't involved in that. When I moved to Iberville in 1988, I started to take an interest. Before, you are young, then you work a lot, [...] you are busy, then there are the children, then all that, so no. I wasn't interested in that (Participant 4). It was when she moved in with her sister and was influenced by her sister that she started voting:

She was a teacher and she was well educated and she used to say "You have to come and vote, get involved, come and vote, it's important". I never voted at the municipal level. I never had the time. You know when something doesn't interest you. [...] But yes, since yes, it interests me, because we are citizens. ...] and then they are human beings [the councillors], and we need someone to represent us. (Participant 4).

\section{Empowering Elders Through the Vote}

According to some theoretical studies, it seems that seniors have the power to claim control over their daily lives by demanding better adapted services (Carette and et Lamont, 1988), and this, by regrouping and voting massively (Viriot-Durandal, 2013). This claim, called the "grey power" is only a theory, but I chose to ask a few questions to find out if the participants consider themselves to have this power of influence in their community.

The thinking of participants on this topic was not the same. For some, there were no specific demands by seniors and they did not believe that they had the power to change things as seniors: "To have renewal, it's not old people who are going to make change. (Participant 16) Still others wonder what they could do to gain some form of power: "What could we do to advocate, to be able to change things ourselves? I don't know" (Participant 18). Others participants demanded the right to equity between young and old: "A spirit of equity. To give to the young, yes, but to give equitably to the older ones as well. (Participant 7). Regarding the power they can wield, Participant 8 suggests going to the city council as a group in order to have leverage: "But, if you all get together and go knock on the city, you're going to be strong as 
hell" (Participant 8). Another participant agreed, adding that "you just have to surround yourself with the right people to be able to advocate" (Participant 3 Participants all agreed that "it's just a matter of time" (Participant 14) before things change.

In order to bring about these changes, 14 of the 19 participants felt that their vote at the municipal level allowed them to contribute to society. Among other things, they felt they could influence those around them by encouraging them to vote: "I think that the influence I can have around me, I have to exercise. I think that everyone, we should all exercise this power, to encourage the people around us, to go in the direction we want to go" (Participant 7). This power of influence is also a way to support their idea as a group, since "there is strength in numbers" (Participant 15). This role is therefore not individual, but collective. It is in groups that they will be able to present ideas, among others, to the city council: "If we went as a group to the city council, we form a small group and we go." (Participant 13) Finally, a last contribution coming from their vote is to claim their right: "I find it hard to give up, I still defend myself. ...] For me, if you don't do anything, it's certain that you won't get anything. But if you fight, then if they [the counselors] don't move forward, you have the right to go to push them in the back and tell them they are no good" (Participant 9). On the other hand, for four participants, their vote at the municipal level does not allow them to contribute to society or at least "not anymore" (Participant 2).

In short, participants' capacity to act is perceived by them through their role in the city, although some do not consider that their contribution, through their volunteer involvement or their vote, offers them a particular role in society.

\section{DISCUSSION AND CONCLUSION}

These results answer our original question (Why do older people care about municipal elections in Quebec? First, for participants, voting at the municipal level is seen as an important duty and right, confirming Charpentier and et al. (2004) study of this age group and voting at other levels of government. The results provide insight into the idea of a duty and a right is also shared for this level of government. For Blais, this sense of duty should be seen as a "moral obligation" to vote (Blais, 2000, p.112). If a voter does not vote, he or she would feel guilty for not doing so. Blais also adds that the sense of civic duty would be deeper among women and older, more religious people. Among our participants, both women and men mentioned that voting was a duty. However, it is not possible for me to affirm or deny the statement related to the participants' religiosity, since I did not ask for this information. As Blais (2000) mentions, all the participants who said that voting was a duty always voted, and this, in all the elections of the different levels of government.

However, our results do not go in the same direction as Perrineau (2007), explaining that voting is an individualistic act and a political act used like any other action. In comparison to our study, Perrineau was interested in all French voters and in the different French elections. On the other hand, only a minority of our participants say they have participated in a demonstration or signed a petition, while the vast majority go to the polls (remember that only one participant says he does not vote at the municipal level). This is similar to other studies showing that few people take part in nonconventional political participation like these (Norris, 2002). In addition, some participants mentioned that they were not aware of any petition campaigns that had taken place in SaintJean-sur-Richelieu. Therefore, the city may not have organized one. For some of our participants, municipal voting offers them the possibility of controlling the elections and the political situation by being able to choose the candidates who will become their representatives. It is also a way for them to let their councillor know whether or not they value their work. Moreover, for our participants, voting has an almost sacred meaning, since compared to other countries, they have the chance to exercise this vote and express their demands, which is not the case with other political actions used by some of the participants. The vote at the municipal level, therefore, does not have the same meaning as any other means of action, as expressed by Perrineau.

Second, senior participants told me that their vote today has a different scope than when they were younger. Some participants explained that they have a better knowledge of the municipal world and are better equipped to look for the right information to vote. This is not unrelated to the results of the study by (Breux and et Vallette, 2020), which showed that young Montreal voters, aged 18 to 35 , look to their parents for information about municipal elections. The authors explain that young voters have not yet learned about the municipal political system, making it impossible for them to acquire information on their own. Instead, our results show that seniors have experienced municipal political government through their community involvement and participation in municipal councils. They no longer need to rely on others to provide them with the information they need to vote: they seek the information themselves. What is peculiar about the results is that none of the older voters who participated in the research mentioned that the usefulness of municipal political parties in learning more about their city. In the 2017 municipal elections, the city of SaintJean-sur-Richelieu featured three different political parties.

In addition, most seniors use some of the municipal services. Services that young people have not yet had the opportunity to use, as they do not own them. The questionnaire we provided to participants tells us that the majority of them are homeowners. According to some participants, home ownership has increased their interest in voting at the municipal level, and has even become a necessity in order to meet their expectations in terms of municipal services. These results confirm (Couture et al., 2014) assertion that homeowners vote more than renters because they have better access to political information and use municipal services more. Based on the fact that the research participants are seniors and that they are homeowners and have learned to understand how the municipal political system works (information), the results thus allow us to affirm that the "age" variable does have an effect on the "political information" variable (political acquisition). When you become a homeowner, you are interested in your tax bill and therefore you are more informed about the political decisions made on this subject. 
Our interviews show that the municipal scene is an important element in the importance that participants attach to their vote. One participant mentioned that she chose her candidate based on who proposed a municipal identity following the 2001 municipal merger. Another participant mentioned that the importance of his vote has changed since the merger. His vote had a greater significance before the merger and the significance is lower since he is voting for the mayor of the large city of Saint-Jeansur-Richelieu than for the mayor of his former home town, one of the current sectors of the city. This is reminiscent of HoffmannMartinot (1992), Champagne (2007) comments explaining that the feeling of belonging to the municipality and the rooting in it incites a resident to vote in municipal elections. However, more interestingly, some participants also felt that the majority of residents were not aware of the importance of the municipality in their lives. Also, the majority of participants consider that voting at the municipal level is useful since it is the closest election to the citizen and allows for the election of a councillor who will be closer to the citizen than those elected at other levels of government. This is what makes the municipal level more important than other levels of government, the proximity to elected officials. Among seniors, voting at the municipal level is expressed through a personalization of the relationship with the municipal councillor. However, this raises several questions about which senior voters do not consider the municipal level to be more important; do they not have this privileged relationship with their councillor? Is it that they are less satisfied with municipal services? Or is it because they feel less attached to the city?

Finally, our results allow us to link the importance of their vote to the grey power theory. Some of the participants in Saint-Jeansur-Richelieu expressed having an influential role through their vote at the municipal level. It is a role that needs to be played by many, as the participants' mention. We therefore conclude that some seniors know that their democratic weight can make a difference in municipal elections. They need to get together, share their needs and demands and vote with the same ambition.

Most importantly, the research findings help to explain why seniors consider it important to vote at the municipal level. First, for seniors, voting at all levels is important because it is a duty and a right. Particularly at the municipal level, this duty is related to exercising power by expressing their voice on political decisions and directly choosing their representative. Second, access to political knowledge, linked to access to property and life experiences, provides seniors with an awareness of their civic duty and the relevance of their vote. With knowledge, seniors no longer have to rely on relatives to make their voting choices. They are now equipped to vote at the municipal level. Third, seniors value their proximity to elected officials more than political platforms. Since the municipal level is the only level that allows voters to vote directly for their mayor (direct voting for the Prime Minister does not exist for provincial and federal elections), seniors feel that the elected official must be responsive to their expectations and be present and easily accessible. Finally, although this is not the case for all seniors who participated in the research, voting at the municipal level gives them the opportunity to contribute to society.

To conclude with the results of this research, I recall that the municipality chosen is a medium-sized municipality where there was no information yet on the effect of this size of municipality and the proximity with the voters. It is possible to say from the evidence that proximity to elected officials is important for older voters, as it might be for smaller municipalities. With regard to the average size of the municipality and the social pressure exerted by a citizen's social network on political participation, the research does not allow us to draw any conclusions, nor was this its objective.

These findings apply only to our sample, of course, and are therefore only limited. Language issues, voter turnout, social background, age diversity, social and political commitments, and the very fact that they chose to participate in our interviews all point to biases in my sample. This research differs from other research, however, in that it focuses on the meaning and importance associated with the municipal level among senior voters and non-voters, rather than on the explanatory factors of voting behaviour. This is an innovation that has not been yet explored in electoral studies.

This research finally provides insight into the importance that a specific political level can have among a segment of the electorate that is often left out. It also demonstrates what the importance of voting at the municipal level is given by the elderly, namely 1) the exercise of a duty, 2) access to property and political information, 3) the proximity of elected officials, and 4) the influential role of seniors. This last element remains to be explored and analyzed with the theories of critical gerontology. Further research on representations of aging and voting behaviour at the municipal level would provide a better understanding of why seniors vote.

\section{DATA AVAILABILITY STATEMENT}

The datasets presented in this article are not readily available because Due to the nature of this research, participants of this study did not agree for their data to be shared publicly, so supporting data is not available. Requests to access the datasets should be directed to Salomé Vallette, salome. vallette@inrs.ca.

\section{ETHICS STATEMENT}

The studies involving human participants were reviewed and approved by Comité d'éthique en recherche avec des êtres humains de l'INRS. The patients/participants provided their written informed consent to participate in this study. Written informed consent was obtained from the individual(s) for the publication of any potentially identifiable images or data included in this article.

\section{AUTHOR CONTRIBUTIONS}

I contributed to the design and implementation of the research, to the analysis of the results and to the writing of the manuscript. 


\section{REFERENCES}

Baribeau, C., and Royer, C. (2013). L'entretien individuel en recherche qualitative : usages et modes de présentation dans la Revue des sciences de l'éducation. rse 38 (1), 23-45. doi:10.7202/1016748ar

Baribeau, C. (2009). Analyse des Données des Entretiens de Groupe. Rech. Qual. 28 (1), 133-148. doi:10.7202/1016748ar

Bherer, Laurence., and et Breux, Sandra. (2011). « Démocratie Locale et éLections: Prémices D’une Comparaison. Les élections municipales au Québec: Enjeux et perspectives, sous la dir. de Sandra Breux et Laurence Bherer. Québec city, Canada: Québec: Presses de l'Université Laval, 1-25.

Binstock, Robert. H., and et Day, Christine. L. (1996). in «Aging and Politics». Dans Handbook of Aging and the Social Sciences. Editors dir. sous la, H. de Robert, and K. George. Binstock et Linda (Academic Press).

Blais, A., and Dobrzynska, A. (1998). Turnout in Electoral Democracies. Eur. J. Polit. Res 33, 239-261. doi:10.1111/1475-6765.00382

Blais, A., Gidengil, E., Nevitte, N., and Nadeau, R. (2004). Where Does Turnout Decline Come from? Eur. J. Polit. Res 43 (2), 221-236. doi:10.1111/j.14756765.2004.00152.x

Blais, André. (2000). "Is it a Duty to Vote?" in To Vote or Not to Vote: The Merits and Limits of Rational Choice Theory. Editor dir. sous la (Pittsburgh: de André BlaisUniversity of Pittsburgh Press), 92-114.

Blais, André. (2002). de André Blais, Elisabeth Gidengil, Richard Nadeau et Neil Nevitte. Peterborough, ON: Broadview Press. "Why was turnout so low? "In Anatomy of a liberal victory: Making sense of the vote in the 2000 Canadian election, sous la dir.

Blais, A. (2006). What Affects Voter Turnout? Annu. Rev. Polit. Sci. 9 (1), 111-125. doi:10.1146/annurev.polisci.9.070204.105121

Breux, Sandra. (2013). " À quoi servent les partis politiques municipaux? " Relations (768), 16.

Breux, S., Couture, J., and Goodman, N. (2017). Fewer Voters, Higher Stakes? the Applicability of Rational Choice for Voter Turnout in Quebec Municipalities. Environ. Plann. C: Polit. Space 35 (6), 990-1009. doi:10.1177/0263774x16676272

Breux, S., and et Couture, J. (2018). Accountability and Responsiveness at Municipal Level: Views from Canada. Montreal: McGill-Queen's University Press.

Breux, S., and Vallette, S. (2020). Voter à l'échelle municipale au Québec : significations et portée chez certains jeunes électeurs. Revue Jeunes et Société 5 (1), 50-70. doi:10.7202/1070525ar

Campbell, A. L., and Binstock, R. H. (2011). " "Politics and Aging in the United States "," in Handbook of Aging and the Social Sciences. Editors dir. sous la, de. R. H. Binstock, and L. K. George (,York: Elsevier).

Cancela, J., and Geys, B. (2016). Explaining Voter Turnout: A Meta-Analysis of National and Subnational Elections. Elect. Stud. 42, 264-275. doi:10.1016/ j.electstud.2016.03.005

Carette, J., and Lamont, S. (1988). À propos des pouvoirs gris. Nouvelles pratiques sociales 1 (1), 133-142. doi:10.7202/301012ar

Chaire de recherche sur la démocratie et les institutions parlementaires (2014). " Nouvelle étude sur la participation électorale à l'élection du 7 avril 2014 ». Québec city, Canada: Université Laval. Available at: http://www.fss.ulaval.ca/ cms_recherche/upload/chaire_democratie/fichiers/participation2014_version_ finale.pdf.

Champagne, P. (2007). « Élections municipales 2005. Portrait de l'élection sans opposition. Muni-stat (bulletin statistique) 2 (1), 1-6.

Charpentier, M., Quéniart, A., Guberman, N., and Blanchard, N. (2004). Les femmes aînées et l'engagement social : une analyse exploratoire du cas des Mémés déchaînées. Lsp (51), 135-143. doi:10.7202/008876ar

CMB-BMC (2020). Canadian Municipal Barometer - Le Baromètre municipal du Canada. Available at: http://www.cmb-bmc.ca/.

Collin, Jean-Pierre., and et Bherer, Laurence. (2009). Montréal: Institution national de la recherche scientifique. Centre - Urbanisation Culture Société.Le mode de scrutin proportionnel à l'échelle municipale: réflexions et leçons tirées de l'examen du cas montréalais.

Couture, J., Breux, S., and Bherer, L. (2014). Analyse écologique des déterminants de la participation électorale municipale au Québec. Can. J. Pol. Sci. 47 (4), 787-812. doi:10.1017/s0008423914001152
Cutler, F., and Matthews, J. S. (2005). The Challenge of Municipal Voting: Vancouver 2002. Can. J. Pol. Sci. 38 (2), 359-382. Available at: http://www. jstor.org/stable/25165809. doi:10.1017/s0008423905040151

Dassonneville, Ruth. (2017). “Age and Voting,". (Dir.) in The Handbook of Electoral Behavior. Editors K. Arzheimer, J. Evans, and M. S. Lewis-Beck (Thousand Oaks: Sage Publications), 137-158.

Davidson, S. (2014). Older Voters: A Phantom Tyranny of Numbers? A Response to Berry: Young People and the Ageing Electorate: Breaking the Unwritten Rule of Representative Democracy. Parliamentary Aff. 67 (3), 726-738. doi:10.1093/ $\mathrm{pa} / \mathrm{gss} 063$

Downs, A. (1957) An Economic Theory of Democracy New York, NY: Harper, 260.

Eidelman, G., and Taylor, Z. 2010. Canadian Urban Politics: Another "Black Hole"? »J. Urban Aff. 32 (3): 305-320. doi:10.1111/j.1467-9906.2010.00507.x

Elder, G. H., Johnson, M. K., and Crosnoe, R. (2003). The Emergence and Development of Life Course Theory. Handbook of the life course, 3-19. doi:10.1007/978-0-306-48247-2_1

Elder, Glen. H. (1998). “" the Life Course and Human Development,” in Handbook of child psychology, sous la dir. Editor M. de Richard (Lerner. NY: Wiley and Sons).

Élections Canada (2016). Taux de participation électorale par groupe d'âge. Available at: http://www.elections.ca/content.aspx?section=res\&dir=rec/eval/ pes2015/vtsa\&document=table1\&lang=f (Consulté le Consulté le décembre 03, 2017).

Élections Québec (2021). Partis Politiques. Available at: https://www. electionsquebec.qc.ca/francais/municipal/repaq/consultation-partis-politiques.php.

Endersby, J. W., and Krieckhaus, J. T. (2008). Turnout Around the Globe: The Influence of Electoral Institutions on National Voter Participation, 1972-2000. Elect. Stud. 27 (4), 601-610. doi:10.1016/j.electstud.2008.05.004

Franklin, M. N. (2004). Voter Turnout and the Dynamics of Electoral Competition in Established Democracies since 1945. Cambridge: Cambridge University Press.

Geys, B. 2006. Explaining Voter Turnout: A Review of Aggregate-Level Research. » Elect. Stud. 25 (4): 637-663. doi:10.1016/j.electstud.2005.09.002

Gherghel, Ana., and et Saint-Jacques, Marie-Christine. (2013). La théorie $d u$ parcours de vie (life course) : une approche interdisciplinaire dans l'étude des familles. Québec: Presses de l'Université Laval, [2013]. Book. Available at: http://ezproxy.usherbrooke.ca/login?url=https://search.ebscohost. com/login.aspx?direct $=$ true $\& \mathrm{db}=$ cat04883a\&AN $=$ sher. i9782763718392\&lang=fr\&site=eds-live.

Goerres, A. (2008). The Grey Vote: Determinants of Older Voters' Party Choice in Britain and West Germany. Elect. Stud. 27 (2), 285-304. doi:10.1016/ j.electstud.2007.12.007

Gutzke, A. M. (2021). Municipal Election in Quebec: How Political Parties Can Strengthen the Democratic Process. Online on the Center for Urban Policy and Local Governance of the Western University. Available at: https://storymaps. arcgis.com/stories/7df251bfd637442386ef42066e5e72e6.

Hoffmann-Martinot, V. (1992). La participation aux élections municipales dans les villes françaises. $r f s p 42$ (1), 3-35. doi:10.3406/rfsp.1992.404274

INSPQ (2019). Les compétences et les pouvoirs des municipalités pour créer des environnements favorables à la saine alimentation et au mode de vie physiquement actif. Available at: https://www.inspq.qc.ca/sites/default/ files/publications/2528_pouvoirs_municipalites_environnements_saine_ alimentation_mode_vie_actif.pdf.

ISQ, Institut de la statistique du Québec (2015). Bilan démographique du Québec. Éditeur officiel du Québec. Available at: http://www.stat.gouv.qc.ca/statistiques/ population-demographie/bilan2015.pdf.

Jennings, M. K. (1979). Another Look at the Life Cycle and Political Participation. Am. J. Polit. Sci. 23 (4), 755-771. doi:10.2307/2110805

Joy, M. (2018). Problematizing the Age Friendly Cities and Communities Program in Toronto. J. Aging Stud. 47, 49-56. doi:10.1016/j.jaging.2018.10.005

Laurence, Jean-Christophe. (2021). 14 mars 2021. « Aux Pays-Bas, des élections sur fond de Covid-19 pourraient couronner une fois de plus Mark Rutte, alias « Teflon Mark », le leader du VVD, dans une paysage politique ultra-fragmenté ». Dans La Presse. Available at: https://www.lapresse.ca/international/europe/ 2021-03-14/elections-legislatives-aux-pays-bas/m-teflon-part-favori-malgretout.php.

Lavoie, J. (2017). Le défi d'encourager le vote aux élections municipales. Radio-Canada. En ligne. Available at: https://ici.radio-canada.ca/ 
nouvelle/1060020/defiparticipation- vote-jeunes-elections-municipalesquebec-2017.

Martel, Laurent. (2002). « L'avènement du pouvoir gris. » In Le passage de l'article scientifique au texte vulgarisé: Analyse de la structure, du contenu et de la rhétorique des textes, sous la dir. de Isabelle Saint-Germain. Mémoire de maîtrise: Université de Sherbrooke. Available at: https://savoirs.usherbrooke. ca/handle/11143/2361.

Martinson, M., and Halpern, J. 2011. Ethical Implications of the Promotion of Elder Volunteerism: A Critical Perspective. » J. Aging Stud. 25 (4): 427-435. doi:10.1016/j.jaging.2011.04.003

Mayer, N. (2007). Qui vote pour qui et pourquoi ? Pouvoirs 120 (1), 17-27. doi:10.3917/pouv.120.0017

McGregor, Michael. (2018). Canadian Municipal Election Study/Études sur les élections municipales canadiennes. Consulté le page consultée le 05 février 2018. Available at: https://www.cmes-eemc.ca/propos.

McGregor, M., and Spicer, Z. (2016). The Canadian Homevoter: Property Values and Municipal Politics in Canada. J. Urban Aff. 38 (1), 123-139. doi:10.1111/ juaf. 12178

Mevellec, Anne., Breux, Sandra., and Couture, Jérôme. (2020). "Does the LeftRight Axis Matter in Municipal Elections?” in Voting in Quebec Municipal Elections: A Tale of Two Cities. Editors Éric. Bélanger, Cameron. D. Anderson, and R. Michael McGregor, (dir) (Toronto: Québec city, Canada: University of Toronto Press).

Mevellec, Anne. 2011 « Les élections municipales de 2009 dans les villes moyennes du Québec: entre changement et reconduction. » In Les élections municipales au Québec: Enjeux et perspectives, sous la dir. de Sandra Breux et Laurence Bherer, 289-310. Québec: Les Presses de l'Université Laval.

Milner, H. (2008). "La connaissance poltique et la participation politique chez les jeunes Américains, Canadiens et Québécois,”. (dir.) in L'annuaire du Québec 2008. Editors M. Venne and M. et Fahmy (Montréal: Institut du Nouveau Monde).

Nakhaie, M. R. (2006). Electoral Participation in Municipal, Provincial and Federal Elections in Canada. Can. J. Pol. Sci. 39 (2), 363-390. Available at: http://ezproxy.usherbrooke.ca/login?url=https://search.ebscohost.com/ login. asp $x$ ?direct $=$ true $\& \mathrm{db}=\mathrm{ah} l \& \mathrm{AN}=21617183 \&$ lang $=$ fr\&site $=$ eds-live. doi: $10.1017 / \mathrm{s} 000842390606015 \mathrm{x}$

Nie, N. H., Verba, S., and Kim, J.-o. (1974). Political Participation and the Life Cycle» Political Participation and the Life Cycle. Comp. Polit. 6 (3), 319-340. doi: $10.2307 / 421518$

Norris, Pippa. (2002). Democratic Phoenix. Reinventing Political Activism. Cambridge: Cambridge University Press.

Oliver, J. E. (2000). City Size and Civic Involvement in Metropolitan America. Am. Polit. Sci. Rev. 94 (2), 361-373. doi:10.3917/pouv.120.0029

Oliver, J. Eric., Ha, Shang. E., and Callen, Zachary. (2012). Local Elections and the Politics of Small-Scale Democracy. Princeton, N.J.: Princeton University Press.

Perrineau, P. (2007). Les usages contemporains du vote. Pouvoirs 120 (1), 29-41. doi:10.3917/pouv.120.0029

Pratt, Henry. J. (1993). Gray Agenda: Interest Groups and Public Pensions in Canada, Britain, and the United States. Ann Arbor: University of Michigan Press.
Quadagno, Jill. (1991). States, labor markets, and the future of old-age policy, sous la dir. de John Myles et Jill Quadagno. Philadelphia: Temple University Press." Interest-Group Politics and the Future of U.S. Social Security. ”

Quintelier, E. (2007). Differences in Political Participation between Young and Old People. Contemp. Polit. 13 (2), 165-180. doi:10.1080/13569770701562658

Rochman, J., and Tremblay, D.-G. (2010). Services et Seniors: l'Impact du Programme Mada sur le Développement des Services Municipaux Communautaires et Privés au Québec. Gérontol. Soc. 135 (4), 285-339. doi:10.3917/gs.135.0285

Savoie-Zajc, L. (2009). “"L'entrevue Semi-dirigée »,". Dir. in Recherche sociale : de la problématique à la collecte de données ( $\left.5^{e} e ́ d i t i o n\right)$. Québec. Editor B. Gauthier (Québec: Presses de l'Université du Québec).

Trounstine, J. (2009). All Politics Is Local: The Reemergence of the Study of City Politics. Perspect. Polit. 7 (3), 611-618. doi:10.1017/S1537592709990892

Ulysse, P.-J., and et Lesemann, F. (1997)., 38. Lien social et Politiques.« On ne vieillit plus aujourd'hui de la même façon qu'hier. »

Vincent, J. A. (1999). Politics, Power and Old Age (Rethinking Ageing Series). New York, NY: Open University Press.

Viriot Durandal, Jean-Philippe. (2013). Le pouvoir gris. Sociologie des groupes de pression de retraités. Paris: Presses Universitaires de France.

Viriot Durandal, J. P., Raymond, E., Moulaert, T., and et Charpentier, M. (2015). Droit de vieillir et citoyenneté des aînés: Pour une perspective internationale. Québec city, Canada: Québec, Presses de l'Université du Québec.

Viriot-Durandal, Jean-Philippe. (2012). Le « Pouvoir gris » du lobbying au pouvoir sur soi ». Gérontologie et société 35 (143), 23-38. doi:10.3917/gs.143.0023

Viriot-Durandal, Jean-Pierre., Pihet, Christian., and et Chapon, Pierre-Marie. 2012. Les défis territoriaux face au vieillissement. La documentation Française.

Walker, J. L. (1983). The Origins and Maintenance of Interest Groups in America. Am. Polit. Sci. Rev. 77, 390-406. doi:10.2307/1958924

Wollmann, H. (2016). "Introduction - Les systèmes électoraux des élections municipales, entre démocratie directe et représentative. Les élections locales françaises 2014-2015 36, 231-233. doi:10.3406/coloc.2016.2971

Conflict of Interest: The author declares that the research was conducted in the absence of any commercial or financial relationships that could be construed as a potential conflict of interest.

Publisher's Note: All claims expressed in this article are solely those of the authors and do not necessarily represent those of their affiliated organizations, or those of the publisher, the editors and the reviewers. Any product that may be evaluated in this article, or claim that may be made by its manufacturer, is not guaranteed or endorsed by the publisher.

Copyright ( 2021 Vallette. This is an open-access article distributed under the terms of the Creative Commons Attribution License (CC BY). The use, distribution or reproduction in other forums is permitted, provided the original author(s) and the copyright owner(s) are credited and that the original publication in this journal is cited, in accordance with accepted academic practice. No use, distribution or reproduction is permitted which does not comply with these terms. 